\title{
Article \\ A Numerical Simulation of Radiation Chemistry for Controlling the Oxidising Environment in Water-Cooled Nuclear Power Reactors
}

\author{
Dorota Swiatla-Wojcik (D)
}

check for

updates

Citation: Swiatla-Wojcik, D. A

Numerical Simulation of Radiation Chemistry for Controlling the Oxidising Environment in Water-Cooled Nuclear Power

Reactors. Appl. Sci. 2022, 12, 947.

https: / / doi.org/10.3390/app12030947

Academic Editor: Maria

Filomena Botelho

Received: 20 December 2021

Accepted: 14 January 2022

Published: 18 January 2022

Corrected: 20 December 2022

Publisher's Note: MDPI stays neutral with regard to jurisdictional claims in published maps and institutional affiliations.

Copyright: (C) 2022 by the author. Licensee MDPI, Basel, Switzerland. This article is an open access article distributed under the terms and conditions of the Creative Commons Attribution (CC BY) license (https:// creativecommons.org/licenses/by/ $4.0 /)$.
Institute of Applied Radiation Chemistry, Lodz University of Technology, Zeromskiego 116, 90-924 Lodz, Poland; dorota.swiatla-wojcik@p.lodz.pl

\begin{abstract}
Maintaining the integrity of materials of light-water nuclear power reactors requires the development of effective methods to control and minimise the corrosive environment associated with the radiolysis of a coolant. In this study, the behaviour of the oxidising environment is simulated using a hybrid method. The hybrid method has advantages in that the production of radiolytic species under exposure of the coolant to ionising radiation is simulated while providing material and charge balances. Steady-state concentrations of stable and transient oxidising agents are calculated as a function of radiation composition and dose rate by numerical integration of the system of kinetic equations describing radiation chemistry of neutral water, the alkaline solution, and the hydrogenated systems at $300^{\circ} \mathrm{C}$. The importance of the reactions and equilibria constituting the radiolysis scheme of the coolant is assessed. The influence of the presence of a base and the injected $\mathrm{H}_{2}$ on the yield of key reactions responsible for the formation of the main oxidants $\mathrm{H}_{2} \mathrm{O}_{2}$ and $\mathrm{O}_{2}$ are discussed. Simulation indicated the synergic effect of $\mathrm{H}_{2}$ gas and base added to the coolant on diminishment of the steady-state concentration of oxidants.
\end{abstract}

Keywords: LWR coolant chemistry; chemical kinetics; high-temperature water radiolysis; nuclear power engineering; numerical simulation; sensitivity analysis

\section{Introduction}

Light-water reactors (LWRs), categorised into boiling-water reactors (BWRs) and pressurised-water reactors (PWRs), are the most widespread type of nuclear power reactors [1]. In LWRs, water plays a role of a neutron moderator and a coolant. The cooling water operates at high pressure and temperature conditions $\left(7-7.5 \mathrm{MPa}, 285^{\circ} \mathrm{C}\right.$ in $\mathrm{BWRs}$ and ca. $15.5 \mathrm{MPa}, 315^{\circ} \mathrm{C}$ in PWRs) and is exposed to intense fluxes of gamma rays and fast neutrons [2] (pp. 960-1023). Exposition to ionising radiation results in the formation of transient radical species: hydrated electrons $\left(\mathrm{e}_{\mathrm{aq}}{ }^{\bullet-}\right)$, hydroxyl radicals $(\mathrm{OH})$, hydrogen radical atoms $\left(\mathrm{H}^{-}\right)$, hydroperoxyl radicals $\left(\mathrm{HO}_{2}{ }^{\circ}\right)$, ions: $\mathrm{H}_{3} \mathrm{O}^{+}, \mathrm{OH}^{-}, \mathrm{O}_{2}^{-}, \mathrm{HO}_{2}^{-}, \mathrm{O}^{-}$, and stable molecular products: molecular hydrogen $\left(\mathrm{H}_{2}\right)$, hydrogen peroxide $\left(\mathrm{H}_{2} \mathrm{O}_{2}\right)$, molecular oxygen $\left(\mathrm{O}_{2}\right)$ [3] (pp. 331-364). The stable oxidants $\left(\mathrm{H}_{2} \mathrm{O}_{2}\right.$ and $\left.\mathrm{O}_{2}\right)$ create a corrosive environment contributing significantly to stress corrosion cracking of the structural materials $[1,2,4-6]$. The harmful effect of oxidants is strengthened by the low acidity (low $\mathrm{pH}$ ) of water at the operating temperatures. For example, because the ionic product of water $\left(K_{\mathrm{w}}\right)$ abruptly increases with temperature, the $\mathrm{pH}$ of liquid neutral water is 5.8 at $300{ }^{\circ} \mathrm{C}$, compared with $\mathrm{pH} 7$ at $25^{\circ} \mathrm{C}$. To minimise the concentration of dissolved oxidants and increase $\mathrm{pH}$, the chemicals such as $\mathrm{H}_{2}$, hydrazine $\left(\mathrm{N}_{2} \mathrm{H}_{4}\right)$, ammonia $\left(\mathrm{NH}_{3}\right)$, lithium hydroxide $(\mathrm{LiOH})$ are added to the coolant [1]. A quantitative understanding of how these additives change a corrosive environment in the nuclear core is still insufficient but essential to control stress corrosion cracking and maintain the integrity of materials in reactor circuits. In particular, it is important to estimate critical hydrogen concentration 
$(\mathrm{CHC})$, i.e., the amount of dissolved hydrogen gas needed to suppress the net production of $\mathrm{O}_{2}$ and $\mathrm{H}_{2} \mathrm{O}_{2}$ in the reactor circuit [2] (pp. 960-1023).

Direct measurements of the chemical environment at the reactor core are not feasible because of high pressure, high temperature, and intense radiation field. Analysis of the reactor water is possible only at sampling points far away from circulation lines. Therefore, computer simulation is indispensable to model the radiation chemistry of the coolant under different operational conditions and assess the response of the oxidising environment to the additives $\left(\mathrm{H}_{2}, \mathrm{LiOH}, \mathrm{N}_{2} \mathrm{H}_{4}, \mathrm{NH}_{3}\right)$.

As knowledge of high-temperature water radiolysis develops the simulations have been widely applied to estimate the chemistry of the coolant, both in the core and in associated pipelines [7-14]. Usually, simulation of the coolant chemistry is based on the numerical solution of a set of ordinary differential equations describing reactions of the primary and secondary chemical species, which are formed during the exposition of cooling water to ionising radiation. The reliability of such a simulation largely depends on the accuracy of the input data including rate constants for the zero-, first-, and second-order reactions. The former rate constants are directly related to the radiation chemical yields of the primary species formed in ca. $10^{-7} \mathrm{~s}$ after the ionising event [3] and expressed in the number of species per $100 \mathrm{eV}$ of energy deposited in the medium.

During the past few decades, the input data for the simulation of the high-temperature radiolysis of water have been amassed by several research groups based on the measurements or extrapolation of the data available for lower temperatures $[13,15,16]$. The variations between outputs of simulations using the datasets from different laboratories were examined by Katsumura et al. [13]. These authors found variations particularly resulting from uncertainties in the primary yields of $\mathrm{OH}, \mathrm{H}_{2}$, and $\mathrm{H}_{2} \mathrm{O}_{2}$ for neutron radiolysis, and confirmed the significance of reaction (42) between $\mathrm{H}^{\prime}$ and $\mathrm{H}_{2} \mathrm{O}$ (Table 2) indicated by the earlier simulations of the coolant chemistry $[8,10]$. Later simulation using the hybrid method showed that the uncertainty in the rate constant of $5 \times 10^{3} \mathrm{M}^{-1} \mathrm{~s}^{-1}$ may result in the unsureness of the estimated steady-state concentration of $\mathrm{H}_{2}, \mathrm{H}_{2} \mathrm{O}_{2}$, and $\mathrm{O}_{2}$ of 17,9 , and $4 \mu \mathrm{M}$, respectively [14].

Since 2005, the role of reaction (42) in the radiolysis of water at high temperatures has been under intensive scientific debate [17-22]. One of the difficulties in recognising the importance of water oxidation by $\mathrm{H}^{\prime}$ in the liquid phase results from high activation energy [19] and a negligibly slow rate at ambient conditions $[18,19,23]$. The latest pulse radiolysis measurements in an aqueous iodide solution showed an increase in the rate constants, from ca. $4 \times 10^{3}$ to $6 \times 10^{4} \mathrm{M}^{-1} \mathrm{~s}^{-1}$, in a temperature range of $270-350{ }^{\circ} \mathrm{C}$ [22]. These measurements confirmed earlier evaluations using thermodynamics [19] and muonium chemistry [21].

In this study, we exploited the hybrid method for numerical simulation of LWR coolant chemistry [14] and the measured high-temperature rate of water oxidation by $\mathrm{H}^{\cdot}[22]$ to identify the principal reactions responsible for the production of oxidants in the pressurised liquid water exposed to gamma $(\gamma)$ and fast neutron radiation at $300{ }^{\circ} \mathrm{C}$. Steady-state concentrations of oxidants calculated assuming averaged values of reaction rate constants reported from different laboratories are presented for mixed radiation as a function of gamma to fast neutron dose rate ratio ranging from 0 to 1 . The effectiveness of additives such as $\mathrm{H}_{2}$ and $\mathrm{LiOH}$ in suppressing the production of stable oxidants is simulated and discussed.

\section{Materials and Methods}

Numerical simulations were performed using the hybrid method, described in detail elsewhere [14] and schematically illustrated in Scheme 1. The concept of the hybrid method is to combine diffusion-kinetic calculation for the radiolytic species initially clustered in radiation tracks and kinetic calculation of reactants homogenously distributed in the bulk solvent. Numerical integration of a set of diffusion-kinetic equations up to $0.1 \mu$ s provided the primary yields (or G values) of the primary species $\left(\mathrm{e}_{\mathrm{aq}}{ }^{\bullet-},{ }^{\bullet} \mathrm{OH}, \mathrm{H}^{\bullet}, \mathrm{H}^{+}, \mathrm{OH}^{-}, \mathrm{H}_{2}\right.$, 
$\mathrm{H}_{2} \mathrm{O}_{2}, \mathrm{HO}_{2}{ }^{\bullet}$ ). The primary yields, still often expressed in molecules per $100 \mathrm{eV}$ of absorbed energy, were then recalculated to production rates $P_{\mathrm{i}}$ according to the required dose rate. Simulations were performed for the dose rates of 1 and $10 \mathrm{kGy} \cdot \mathrm{s}^{-1}$, which are similar to the in-core dose rates of gamma and fast neutron radiation.

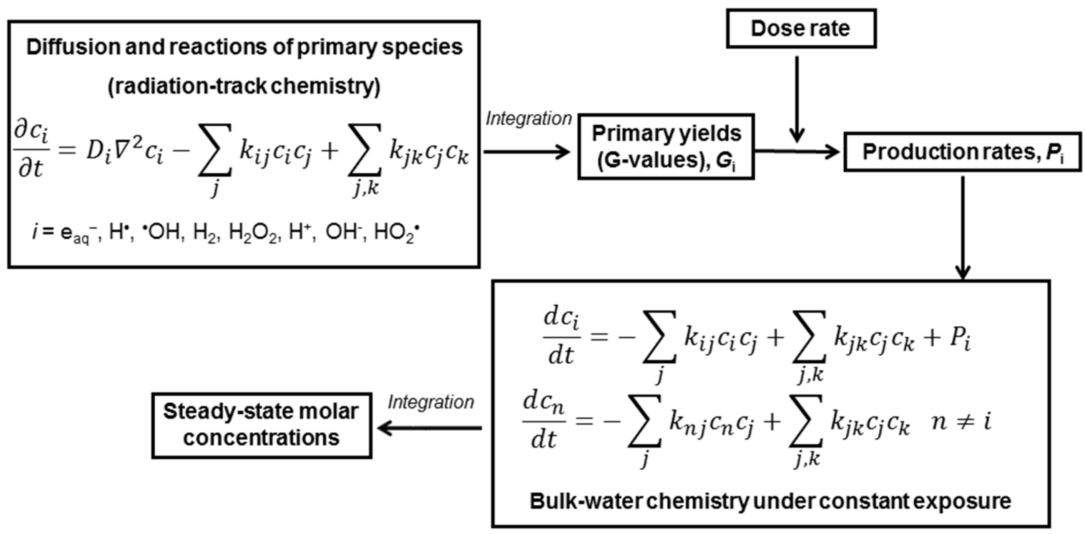

Scheme 1. Schematic illustration of the hybrid method [14]: $c_{\mathrm{i}}$ and $D_{\mathrm{i}}$ are molar concentrations and diffusion coefficients of the primary species; $P_{\mathrm{i}}\left(\right.$ in $\left.\mathrm{M} \cdot \mathrm{s}^{-1}\right)=1.0364 \cdot 10^{-7} \cdot G_{\mathrm{i}}$ (in molecules per $100 \mathrm{eV}) \cdot\left(\right.$ dose rate in $\left.\mathrm{Gy} \cdot \mathrm{s}^{-1}\right) \cdot\left(\right.$ water density in $\left.\mathrm{kg} \cdot \mathrm{dm}^{-3}\right)$ is a production rate of the $i$-th primary species under constant exposure to ionising radiation.

Table 1 presents production rates $P_{\mathrm{i}(\mathrm{g})}$ and $P_{\mathrm{i}(\mathrm{n})}$, obtained for gamma and fast neutron radiolysis of water at $300{ }^{\circ} \mathrm{C}$. For mixed radiation, production rates were calculated using the equation $P_{\mathrm{i}(\operatorname{mix})}=f_{\mathrm{g}} P_{\mathrm{i}(\mathrm{g})}+f_{\mathrm{n}} P_{\mathrm{i}(\mathrm{n})}$, where $f_{\mathrm{g}}+f_{\mathrm{n}}=1$.

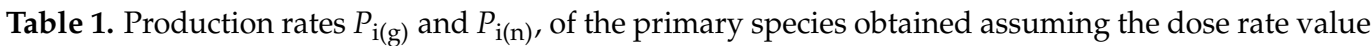
of $1 \mathrm{kGy} \cdot \mathrm{s}^{-1}$ and using the $\mathrm{G}$ values for gamma and fast neutron radiolysis of water at $300{ }^{\circ} \mathrm{C}$ from ref. [14]. Last row describes loss of water molecules resulting from irradiation.

\begin{tabular}{ccc}
\hline Species $\boldsymbol{i}$ & $\boldsymbol{P}_{\mathbf{i}(\mathbf{g}), \mathbf{M} \cdot \mathbf{s}^{-\mathbf{1}}}$ & $\boldsymbol{P}_{\mathbf{i}(\mathbf{n})}, \mathbf{M} \cdot \mathbf{s}^{-\mathbf{1}}$ \\
\hline $\mathrm{e}_{\mathrm{aq}}{ }^{\bullet}$ & $2.385 \cdot 10^{-4}$ & $1.062 \cdot 10^{-4}$ \\
$\mathrm{H}^{\bullet}$ & $5.970 \cdot 10^{-5}$ & $5.455 \cdot 10^{-05}$ \\
$\mathrm{H}^{+}$ & $2.837 \cdot 10^{-4}$ & $1.453 \cdot 10^{-4}$ \\
$\bullet$ & $3.564 \cdot 10^{-4}$ & $2.730 \cdot 10^{-4}$ \\
$\mathrm{H}_{2} \mathrm{O}_{2}$ & $1.866 \cdot 10^{-5}$ & $3.201 \cdot 10^{-5}$ \\
$\mathrm{H}_{2}$ & $4.776 \cdot 10^{-5}$ & $8.895 \cdot 10^{-5}$ \\
$\mathrm{HO}_{2}$ & 0 & $5.584 \cdot 10^{-7}$ \\
$\mathrm{OH}^{-}$ & $4.522 \cdot 10^{-5}$ & $3.910 \cdot 10^{-5}$ \\
$-\mathrm{H}_{2} \mathrm{O}$ & $3.937 \cdot 10^{-4}$ & $3.387 \cdot 10^{-4}$ \\
\hline
\end{tabular}

The advantage of employing the hybrid method is that the production of primary radiolytic species satisfies both the material balance and the charge balance. At the concentration of additives $\left[\mathrm{OH}^{-}\right]=2 \cdot 10^{-4} \mathrm{~mol} \cdot \mathrm{kg}^{-1}$ and $\left[\mathrm{H}_{2}\right] \leq 1.5 \cdot 10^{-4} \mathrm{~mol} \cdot \mathrm{kg}^{-1}$, considered in this study, the production rates for alkaline and hydrogenated solutions can be assumed the same as for neutral water at $300{ }^{\circ} \mathrm{C}$ [24].

The production rates specified in Table 1 were used as zeroth-order terms in a system of differential kinetic equations, which was defined with respect to 13 species (i.e., $\mathrm{e}_{\mathrm{aq}}{ }^{\bullet-}$, ${ }^{\bullet} \mathrm{OH}, \mathrm{H}^{\bullet}, \mathrm{OH}^{-}, \mathrm{H}_{2} \mathrm{O}, \mathrm{H}_{2}, \mathrm{H}_{2} \mathrm{O}_{2}, \mathrm{O}_{2}, \mathrm{O}_{2}^{\bullet-}, \mathrm{HO}_{2}^{\bullet}, \mathrm{HO}_{2}^{-}, \mathrm{H}_{2}, \mathrm{H}_{2} \mathrm{O}_{2}, \mathrm{O}^{\bullet-}, \mathrm{O}_{3}^{\bullet-}$, $\mathrm{O}^{\bullet}$ ) involved in the 1 st and 2 nd order reactions listed in Table 2 . The reaction set and the associated high-temperature rate constants were compiled based on the data reported from different laboratories. 
Table 2. Reaction set for the radiolysis of high-temperature water and rate constants $k$ at $300{ }^{\circ} \mathrm{C}$ (units for 2 nd and 1 st order reactions are $\mathrm{M}^{-1} \cdot \mathrm{s}^{-1}$ and $\mathrm{s}^{-1}$, respectively). For reactions between similar species, the value of $k$, not $2 k$, is given.

\begin{tabular}{|c|c|c|c|c|c|}
\hline No. & Reaction & $k\left(300^{\circ} \mathrm{C}\right)$ & No. & Reaction & $k\left(300{ }^{\circ} \mathrm{C}\right)$ \\
\hline $1^{1}$ & $\mathrm{e}_{\mathrm{aq}}^{\bullet-}+\mathrm{e}_{\mathrm{aq}}^{\bullet-} \stackrel{+2 \mathrm{H}_{2} \mathrm{O}}{\rightarrow} \mathrm{H}_{2}+2 \mathrm{OH}^{-}$ & $6.06 \cdot 10^{6}$ & $30^{1}$ & $\mathrm{H}^{+}+\mathrm{HO}_{2}^{-} \rightarrow \mathrm{H}_{2} \mathrm{O}_{2}$ & $5.69 \cdot 10^{11}$ \\
\hline $\begin{array}{l}2^{2} \\
3^{2}\end{array}$ & $\begin{array}{c}\mathrm{H}^{\bullet}+\mathrm{H}^{\bullet} \rightarrow \mathrm{H}_{2} \\
\cdot \mathrm{OH}+\cdot \mathrm{OH} \rightarrow \mathrm{H}_{2} \mathrm{O}_{2}\end{array}$ & $\begin{array}{l}1.01 \cdot 10^{11} \\
1.80 \cdot 10^{10}\end{array}$ & $\begin{array}{l}31^{1} \\
32^{1}\end{array}$ & $\begin{array}{c}\mathrm{H}_{2} \mathrm{O}_{2} \rightarrow \mathrm{H}^{+}+\mathrm{HO}_{2}^{-} \\
\mathrm{H}^{+}+\mathrm{O}^{\bullet-} \rightarrow \bullet \mathrm{OH}\end{array}$ & $\begin{array}{l}2.52 \cdot 10^{1} \\
5.69 \cdot 10^{11}\end{array}$ \\
\hline $4^{2}$ & $\mathrm{e}_{\mathrm{ag}}^{\bullet-}+\mathrm{H}^{\bullet} \stackrel{+\mathrm{H}_{2} \mathrm{O}}{\longrightarrow} \mathrm{H}_{2}+\mathrm{OH}^{-}$ & $4.39 \cdot 10^{11}$ & $33^{1}$ & $\cdot \mathrm{OH} \rightarrow \mathrm{H}^{+}+\mathrm{O}^{\bullet-}$ & $2.52 \cdot 10^{1}$ \\
\hline $5^{2}$ & $\mathrm{e}_{\mathrm{aq}}^{\bullet-}+\cdot \mathrm{OH} \rightarrow \mathrm{OH}^{-}$ & $4.69 \cdot 10^{11}$ & $34^{1}$ & $\mathrm{H}_{2} \mathrm{O}_{2}+\mathrm{OH}^{-} \rightarrow \mathrm{HO}_{2}^{-}+\mathrm{H}_{2} \mathrm{O}$ & $1.36 \cdot 10^{11}$ \\
\hline $6^{2}$ & $\mathrm{H}^{\bullet}+\bullet{ }^{\bullet} \mathrm{OH} \rightarrow \mathrm{H}_{2} \mathrm{O}$ & $5.52 \cdot 10^{10}$ & $35^{1}$ & $\mathrm{HO}_{2}^{-}+\mathrm{H}_{2} \mathrm{O} \rightarrow \mathrm{H}_{2} \mathrm{O}_{2}+\mathrm{OH}^{-}$ & $1.76 \cdot 10^{8}$ \\
\hline $7^{2}$ & $\mathrm{e}_{\mathrm{aq}}^{\bullet-}+\mathrm{H}_{2} \mathrm{O}_{2} \rightarrow \mathrm{OH}^{-}+\bullet \mathrm{OH}$ & $2.73 \cdot 10^{11}$ & $36^{1}$ & $\mathrm{HO}_{2}^{\bullet}+\mathrm{OH}^{-} \rightarrow \mathrm{O}_{2}^{\bullet-}+\mathrm{H}_{2} \mathrm{O}$ & $1.36 \cdot 10^{11}$ \\
\hline $8^{2}$ & $\mathrm{e}_{\mathrm{aq}}^{\bullet-}+\mathrm{O}_{2} \rightarrow \mathrm{O}_{2}^{\bullet-}$ & $2.49 \cdot 10^{11}$ & $37^{1}$ & $\mathrm{O}_{2}^{--}+\mathrm{H}_{2} \mathrm{O} \rightarrow \mathrm{HO}_{2}^{\bullet}+\mathrm{OH}^{-}$ & $2.87 \cdot 10^{4}$ \\
\hline $9^{1}$ & $\mathrm{e}_{\mathrm{aq}}^{\bullet-}+\mathrm{O}_{2}^{\bullet-} \stackrel{+2 \mathrm{H}_{2} \mathrm{O}}{\rightarrow} \mathrm{H}_{2} \mathrm{O}_{2}+2 \mathrm{OH}^{-}$ & $1.61 \cdot 10^{11}$ & $38^{1}$ & $\mathrm{H}^{+}+\mathrm{e}_{\mathrm{aq}}^{\bullet-} \rightarrow \mathrm{H}^{\bullet}$ & $7.16 \cdot 10^{11}$ \\
\hline $10^{3}$ & $\mathrm{e}_{\mathrm{aq}}^{\bullet-}+\mathrm{O}_{2}^{\bullet^{-}} \stackrel{+}{\mathrm{H}_{2} \mathrm{O}} \mathrm{HO}_{2}^{-}+\mathrm{OH}^{-}$ & $2.15 \cdot 10^{11}$ & $39^{1}$ & $\mathrm{H}^{\bullet} \rightarrow \mathrm{H}^{+}+\mathrm{e}_{\mathrm{aq}}^{\bullet-}$ & $1.65 \cdot 10^{5}$ \\
\hline $11^{2}$ & $\mathrm{e}_{\mathrm{aq}}^{\bullet-}+\mathrm{HO}_{2}^{\bullet} \rightarrow \mathrm{HO}_{2}^{-}$ & $2.46 \cdot 10^{11}$ & $40^{2}$ & $\mathrm{H}^{\bullet}+\mathrm{OH}^{-} \rightarrow \mathrm{e}_{\mathrm{aq}}^{\bullet-}+\mathrm{H}_{2} \mathrm{O}$ & $2.26 \cdot 10^{10}$ \\
\hline $12^{2}$ & $\mathrm{H}^{\bullet}+\mathrm{H}_{2} \mathrm{O}_{2} \rightarrow \bullet \cdot \mathrm{OH}+\mathrm{H}_{2} \mathrm{O}$ & $1.29 \cdot 10^{9}$ & $41^{2}$ & $\mathrm{e}_{\mathrm{aq}}^{\bullet-}+\mathrm{H}_{2} \mathrm{O} \rightarrow \mathrm{H}^{\bullet}+\mathrm{OH}^{-}$ & $1.16 \cdot 10^{3}$ \\
\hline $13^{2}$ & $\mathrm{H}^{\bullet}+\mathrm{O}_{2} \rightarrow \mathrm{HO}_{2}^{\bullet}$ & $1.11 \cdot 10^{11}$ & $42^{4}$ & $\mathrm{H}^{\bullet}+\mathrm{H}_{2} \mathrm{O} \rightarrow \bullet \cdot \mathrm{OH}+\mathrm{H}_{2}$ & $3.04 \cdot 10^{4}$ \\
\hline $14^{3}$ & $\mathrm{H}^{\bullet}+\mathrm{HO}_{2}^{\bullet} \rightarrow \mathrm{H}_{2} \mathrm{O}_{2}$ & $3.31 \cdot 10^{11}$ & $43^{2}$ & $\bullet \cdot \mathrm{OH}+\mathrm{H}_{2} \rightarrow \mathrm{H}^{\bullet}+\mathrm{H}_{2} \mathrm{O}$ & $1.15 \cdot 10^{9}$ \\
\hline $15^{1}$ & $\mathrm{H}^{\bullet}+\mathrm{HO}_{2}^{\bullet} \rightarrow 2^{\bullet} \mathrm{OH}$ & $2.14 \cdot 10^{11}$ & $44^{1}$ & $\cdot \mathrm{OH}+\mathrm{HO}_{2}^{-} \rightarrow \mathrm{H}_{2} \mathrm{O}+\mathrm{O}_{2}^{\bullet-}$ & $8.18 \cdot 10^{10}$ \\
\hline $16^{2}$ & $\mathrm{H}^{\bullet}+\mathrm{O}_{2}^{\bullet^{-}} \rightarrow \mathrm{HO}_{2}^{-}$ & $2.73 \cdot 10^{11}$ & $45^{3}$ & $\cdot \mathrm{OH}+\mathrm{HO}_{2}^{-} \rightarrow \mathrm{HO}_{2}^{-}+\mathrm{OH}^{-}$ & $1.24 \cdot 10^{11}$ \\
\hline $17^{2}$ & $\cdot \mathrm{OH}+\mathrm{H}_{2} \mathrm{O}_{2} \rightarrow \mathrm{HO}_{2}^{\cdot}+\mathrm{H}_{2} \mathrm{O}$ & $4.35 \cdot 10^{8}$ & $46^{1}$ & $\mathrm{O}^{--}+\mathrm{H}_{2} \mathrm{O}_{2} \rightarrow \mathrm{OH}^{-}+\mathrm{HO}_{2}^{\bullet}$ & $8.18 \cdot 10^{10}$ \\
\hline $18^{2}$ & $\cdot \mathrm{OH}+\mathrm{O}_{2}^{--} \rightarrow \mathrm{O}_{2}+\mathrm{OH}^{-}$ & $2.07 \cdot 10^{11}$ & $47^{1}$ & $\mathrm{O}^{\bullet-}+\mathrm{HO}_{2}^{-} \rightarrow \mathrm{OH}^{-}+\mathrm{O}_{2}^{--}$ & $8.76 \cdot 10^{10}$ \\
\hline $19^{2}$ & $\cdot \mathrm{OH}+\mathrm{HO}_{2}^{\bullet} \rightarrow \mathrm{O}_{2}+\mathrm{H}_{2} \mathrm{O}$ & $7.48 \cdot 10^{10}$ & $48^{1}$ & $\mathrm{O}^{\bullet-}+\mathrm{H}_{2} \rightarrow \mathrm{OH}^{-}+\mathrm{H}^{\bullet}$ & $1.55 \cdot 10^{9}$ \\
\hline $20^{2}$ & $\mathrm{HO}_{2}^{\bullet}+\mathrm{HO}_{2}^{\circ} \rightarrow \mathrm{H}_{2} \mathrm{O}_{2}+\mathrm{O}_{2}$ & $4.51 \cdot 10^{7}$ & $49^{1}$ & $\mathrm{O}^{\bullet-}+\mathrm{O}_{2} \rightarrow \mathrm{O}_{3}^{\bullet-}$ & $3.26 \cdot 10^{10}$ \\
\hline $21^{3}$ & $\mathrm{HO}_{2}^{-}+\mathrm{O}_{2}^{--} \rightarrow \mathrm{HO}_{2}^{-}+\mathrm{O}_{2}$ & $4.31 \cdot 10^{8}$ & $50^{1}$ & $\mathrm{O}_{3}^{\bullet-} \rightarrow \mathrm{O}^{\bullet-}+\mathrm{O}_{2}$ & $1.99 \cdot 10^{7}$ \\
\hline $22^{1}$ & $\mathrm{H}_{2} \mathrm{O}_{2} \rightarrow 0.5 \mathrm{O}_{2}+\mathrm{H}_{2} \mathrm{O}$ & $3.78 \cdot 10^{-2}$ & $51^{3}$ & $\mathrm{O}^{\bullet-}+\bullet \cdot \mathrm{OH} \rightarrow \mathrm{HO}_{2}^{-}$ & $2.98 \cdot 10^{11}$ \\
\hline $23^{1}$ & $\mathrm{H}_{2} \mathrm{O}_{2} \rightarrow 2^{\bullet} \mathrm{OH}$ & $3.78 \cdot 10^{-2}$ & $52^{3}$ & $\mathrm{e}_{\mathrm{aq}}^{\bullet-}+\mathrm{HO}_{2}^{-} \rightarrow \mathrm{O}^{\bullet-}+\mathrm{OH}^{-}$ & $5.79 \cdot 10^{10}$ \\
\hline $24^{1}$ & $\mathrm{H}^{+}+\mathrm{OH}^{-} \rightarrow \mathrm{H}_{2} \mathrm{O}$ & $1.13 \cdot 10^{12}$ & $53^{5}$ & $\mathrm{e}_{3 \mathrm{a}}^{\bullet-}+\mathrm{HO}_{2}^{-} \stackrel{+}{\rightarrow} \stackrel{\mathrm{H}_{2} \mathrm{O}}{\rightarrow} \cdot \mathrm{OH}+2 \mathrm{OH}^{-}$ & $7.12 \cdot 10^{8}$ \\
\hline $25^{1}$ & $\mathrm{H}_{2} \mathrm{O} \rightarrow \mathrm{H}^{+}+\mathrm{OH}^{-}$ & $6.52 \cdot 10^{-2}$ & $54^{3}$ & $\mathrm{O}_{2}^{\bullet-}+\mathrm{HO}_{2}^{\bullet} \rightarrow \mathrm{O}_{2}+\mathrm{HO}_{2}^{-}$ & $4.31 \cdot 10^{8}$ \\
\hline $26^{1}$ & $\mathrm{O}_{2}^{--}+\mathrm{H}^{+} \rightarrow \mathrm{HO}_{2}^{\bullet}$ & $5.69 \cdot 10^{11}$ & $55^{3}$ & ${ }^{\mathrm{H}_{2} \mathrm{O}_{2} \rightarrow \mathrm{O}^{\bullet}+\mathrm{H}_{2} \mathrm{O}}$ & $1.02 \cdot 10^{-2}$ \\
\hline $27^{1}$ & $\mathrm{HO}_{2}^{\bullet} \rightarrow \mathrm{O}_{2}^{\bullet-}+\mathrm{H}^{+}$ & $1.55 \cdot 10^{5}$ & $56^{3}$ & $\mathrm{O}^{\bullet}+\mathrm{O}^{\bullet} \rightarrow \mathrm{O}_{2}$ & $8.28 \cdot 10^{10}$ \\
\hline $28^{1}$ & $\cdot \mathrm{OH}+\mathrm{OH}^{-} \rightarrow \mathrm{O}^{\bullet-}+\mathrm{H}_{2} \mathrm{O}$ & $1.36 \cdot 10^{11}$ & $57^{6}$ & $\mathrm{e}_{0}^{\bullet-}+\mathrm{e}_{0}^{\bullet-}+\stackrel{\mathrm{H}_{2} \mathrm{O}}{\rightarrow} \mathrm{e}_{a-}^{\bullet-}+\mathrm{H}^{\bullet}+\mathrm{OH}^{-}$ & $1.99 \cdot 10^{11}$ \\
\hline $29^{1}$ & $\mathrm{O}^{\bullet-}+\mathrm{H}_{2} \mathrm{O} \rightarrow \bullet \cdot \mathrm{OH}+\mathrm{OH}^{-}$ & $1.76 \cdot 10^{8}$ & & & \\
\hline
\end{tabular}

${ }^{1}$ Temperature dependence recommended in ref. [16]. ${ }^{2}$ Average of the values reported in refs. [15,16]. ${ }^{3}$ Temperature dependence recommended in ref. [15]. ${ }^{4}$ Temperature dependence reported in ref. [22]. ${ }^{5}$ Value from ref. [25] extrapolated to $300^{\circ} \mathrm{C} .{ }^{6}$ Temperature dependence reported from ref. [26].

In order to obtain steady-state concentrations, the system of differential equations was numerically integrated up to the time limit $t_{\max }=100 \mathrm{~s}$ using the FACSIMILE 4 (ver. 4.2.50, MCPA Software, Harwell, UK) package. Except for $\mathrm{H}_{2} \mathrm{O}, \mathrm{H}^{+}$, and $\mathrm{OH}^{-}$, the initial concentration of the reactants was set to zero. The molar concentration of $\mathrm{H}_{2} \mathrm{O}$ was calculated using the density of water at $300{ }^{\circ} \mathrm{C}, 0.72 \mathrm{~kg} \cdot \mathrm{dm}^{-3}$. The initial concentration for $\mathrm{H}^{+}$and $\mathrm{OH}^{-}$, was obtained from the relation $\mathrm{p} K_{\mathrm{w}}=\mathrm{pH}+\mathrm{pOH}$, where $\mathrm{p} K_{\mathrm{w}}$, expressed in molar units, equals 11.64 at $300{ }^{\circ} \mathrm{C}$ [16].

\section{Results}

The results of the kinetic simulations presented here were obtained for neutral water and for an alkaline solution containing $2 \cdot 10^{-4} \mathrm{~mol} \cdot \mathrm{kg}^{-1} \mathrm{LiOH}$ using the reaction scheme and the rate constants from Table 2.

Concentration profiles of the radiolytic species shown in Figure 1 indicate that the steady state is reached after ca. $10 \mathrm{~s}$. Within 10 and $100 \mathrm{~s}$, the relative change in species concentration is less than $0.08 \%$.

The main species responsible for the formation of oxidising environment are oxygen and hydrogen peroxide. The steady-state concentrations of ${ }^{\bullet} \mathrm{OH}$ and $\mathrm{HO}_{2}{ }^{\bullet}$ are lower by about two orders of magnitude. 


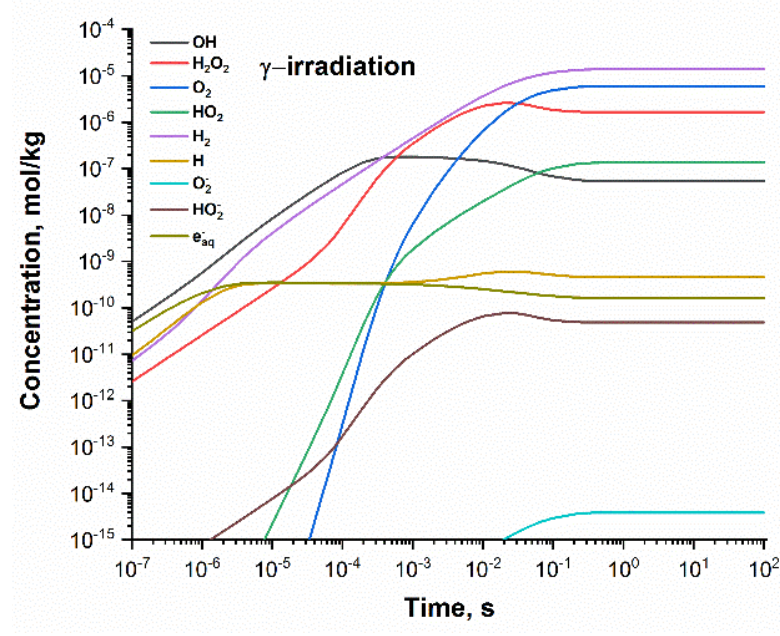

(a)

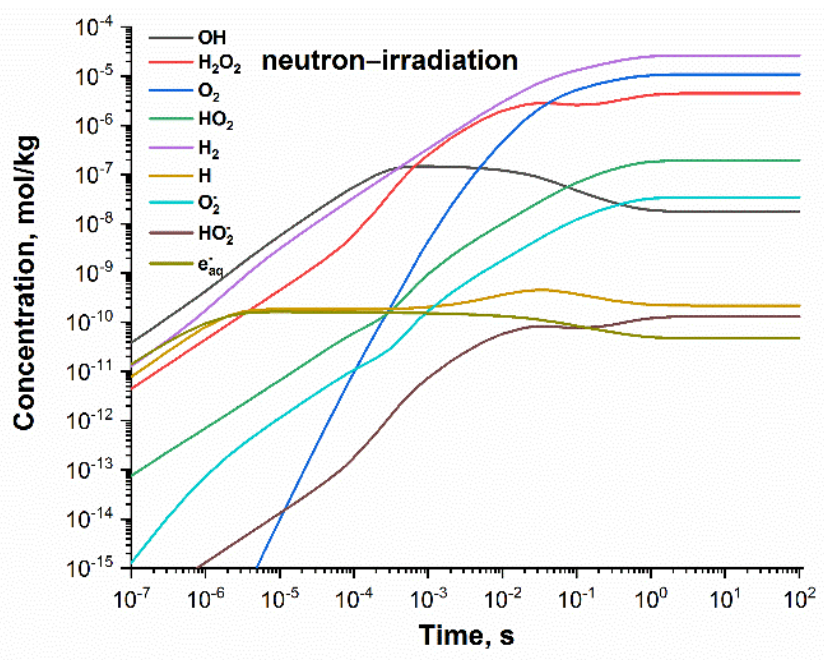

(b)

Figure 1. Concentration profiles of the radiolytic species calculated for neutral deaerated water exposed to (a) gamma and (b) fast neutron radiation at $300{ }^{\circ} \mathrm{C}$ and dose rate $1 \mathrm{kGy} \cdot \mathrm{s}^{-1}$.

\subsection{Main Oxidant Production versus Radiation Composition}

\subsubsection{Neutral Water}

Figure 2 shows the steady-state concentrations of $\mathrm{O}_{2}, \mathrm{H}_{2} \mathrm{O}_{2}, \bullet \mathrm{OH}$, and $\mathrm{HO}_{2} \bullet$ as a function of the fraction of $\gamma$ rays $\left(f_{\mathrm{g}}\right)$ in the mixed gamma-neutron radiolysis of neutral water.

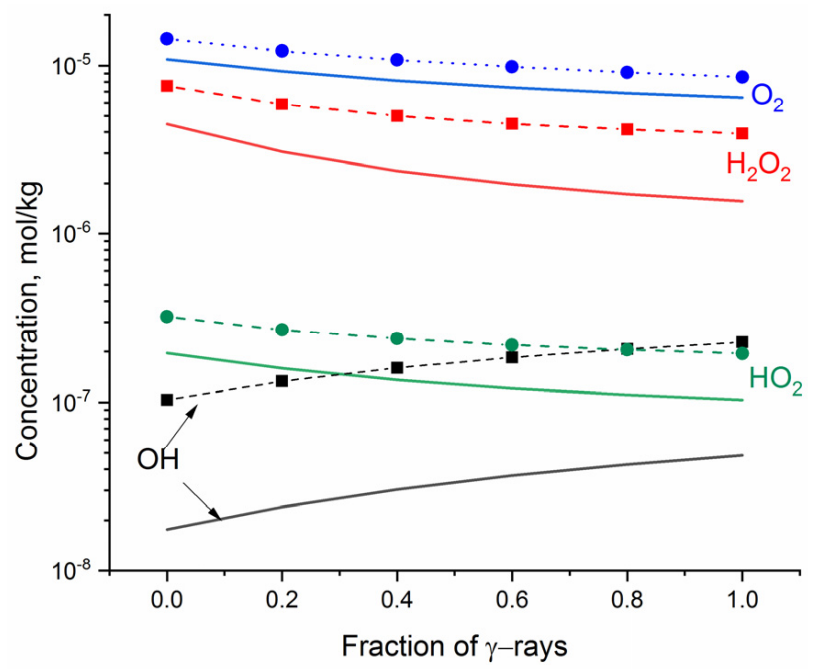

Figure 2. The simulated steady state concentrations of oxidants formed in neutral water vs. fraction of $\gamma$-rays $\left(f_{\mathrm{g}}\right)$ in the mixed gamma-fast neutron radiation: solid lines indicate dose rate of $1 \mathrm{kGy} \cdot \mathrm{s}^{-1}$; dashed + symbol indicates $10 \mathrm{kGy} \cdot \mathrm{s}^{-1}$.

The steady-state concentrations of $\mathrm{O}_{2}, \mathrm{H}_{2} \mathrm{O}_{2}$, and $\mathrm{HO}_{2}{ }^{\bullet}$, obtained for fast neutron radiolysis $\left(f_{\mathrm{g}}=0\right)$, are higher than the concentration of ${ }^{\bullet} \mathrm{OH}$. The increasing fraction of $\gamma$ rays decreases the concentrations of the molecular oxidants but increases the concentration of $\bullet \mathrm{OH}$. This trend is expected since the flux of $2 \mathrm{MeV}$ neutrons produces recoil protons of mean linear energy transfer (LET) 20, 27, 34.5, and $44 \mathrm{eV} \cdot \mathrm{nm}^{-1}$ [16], whereas $\gamma$ rays are representative for low-LET radiation (LET $0.2 \mathrm{eV} \cdot \mathrm{nm}^{-1}$ ), producing higher yields of radical than molecular radiolytic products. The number of generated oxidants depends on the dose rate. A particularly significant increase with increasing dose rate was obtained for $\bullet \mathrm{OH}$ and $\mathrm{H}_{2} \mathrm{O}_{2}$. 
The hybrid method allows one to assess the change in $\mathrm{pH}$ under exposure to ionising radiation. The simulation showed a slight decrease in $\mathrm{pH}$, which is more pronounced for fast neutron radiation - namely, the $100 \mathrm{~s}$ exposure to fast neutrons leads to a decline in $\mathrm{pH}$ by 0.0037 at the radiation dose of $1 \mathrm{kGy} \cdot \mathrm{s}^{-1}$ and by 0.0063 at $10 \mathrm{kGy} \cdot \mathrm{s}^{-1}$, whereas exposure to $\gamma$ rays leads to a decline in $\mathrm{pH}$ by 0.0020 at $1 \mathrm{kGy} \cdot \mathrm{s}^{-1}$ and by 0.0041 at $10 \mathrm{kGy} \cdot \mathrm{s}^{-1}$.

\subsubsection{Alkaline Aqueous Solution}

Figure 3 presents how the addition of base alters the steady state concentrations of $\mathrm{O}_{2}, \mathrm{H}_{2} \mathrm{O}_{2}, \bullet \mathrm{OH}$ and $\mathrm{HO}_{2} \bullet$ in the mixed gamma-neutron radiolysis. Simulations have been performed for fraction of $\gamma$-rays varying from $f_{\mathrm{g}}=0$ (high LET neutron radiolysis) to $f_{\mathrm{g}}=1$ (low-LET gamma radiolysis).

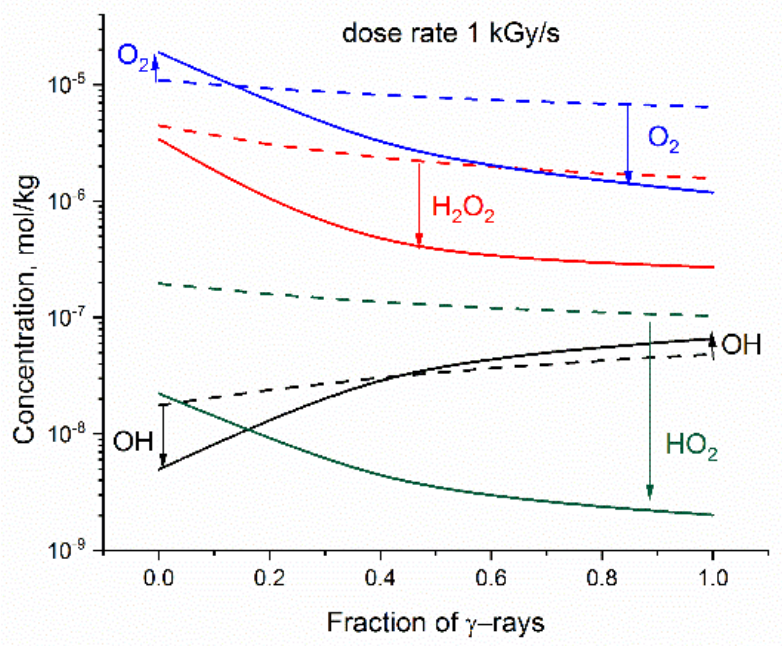

(a)

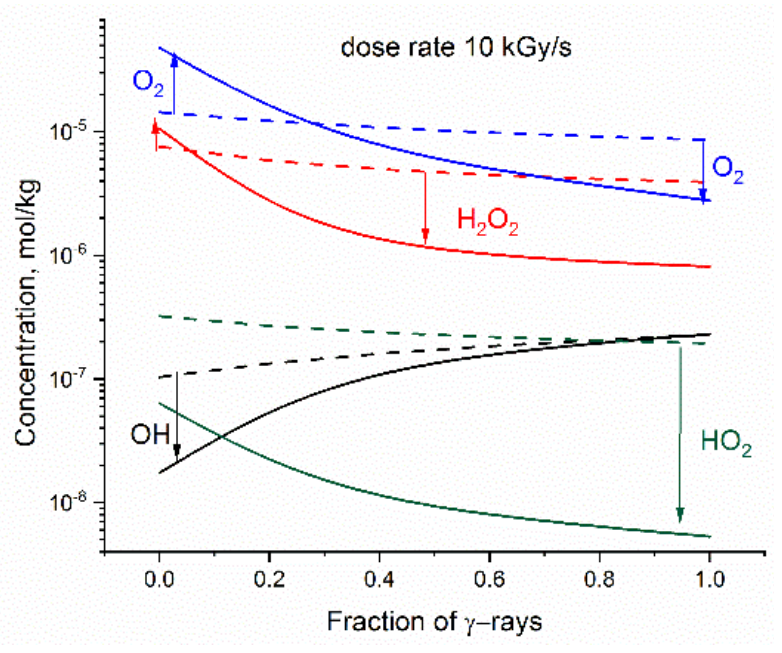

(b)

Figure 3. Simulated changes in the steady state concentrations of oxidants resulting from base addition vs. fraction of $\gamma$-rays in the mixed gamma-fast neutron radiation: (a) dose rate $1 \mathrm{kGy} \cdot \mathrm{s}^{-1}$; (b) dose rate $10 \mathrm{kGy} \cdot \mathrm{s}^{-1}$. The solid and dashed lines refer to $2 \cdot 10^{-4} \mathrm{~mol} \mathrm{~kg}{ }^{-1} \mathrm{LiOH}$ aqueous solution and to neutral water, respectively. The direction of changes is marked by arrows.

In alkaline solution, the steady-state concentration of $\mathrm{HO}_{2} \bullet$ is significantly reduced, irrespective of the dose rate and radiation composition. The influence of these factors is seen, however, in the case of $\mathrm{O}_{2}, \mathrm{H}_{2} \mathrm{O}_{2}$, and ${ }^{\bullet} \mathrm{OH}$. Simulation shows that at a small fraction of gamma radiation, base addition may decrease the amount of ${ }^{\bullet} \mathrm{OH}$ and increase concentration of the stable oxidants $\left(\mathrm{O}_{2}\right.$ and $\left.\mathrm{H}_{2} \mathrm{O}_{2}\right)$. This negative effect of base addition is less pronounced at $1 \mathrm{kGy} \cdot \mathrm{s}^{-1}$.

\subsection{Effectiveness of Hydrogen Addition in Suppressing Production of Stable Oxidants}

Molecular hydrogen is one of the reducing products of water radiolysis, but the amount of radiolytic $\mathrm{H}_{2}$ is not enough to suppress the formation of stable oxidants. Therefore, to change the oxidising conditions into the reducing ones, hydrogen gas was injected into the coolant. Hydrogen injection promotes reaction (43), converting $\mathrm{OH}$ into the reducing $\mathrm{H}$ radical atom, which initiates the transformation of $\mathrm{O}_{2}$ to $\mathrm{H}_{2} \mathrm{O}$ in a sequence of reactions, as illustrated in Scheme 2. 


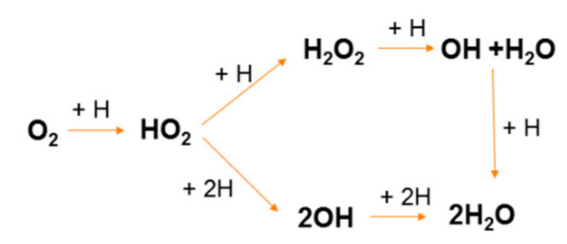

Scheme 2. Sequence of hydrogen atom reactions leading to conversion of $\mathrm{O}_{2}$ into $\mathrm{H}_{2} \mathrm{O}$.

Numerical simulations were performed for fast neutron and gamma radiolysis of neutral water and the alkaline solution $\left(2 \cdot 10^{-4} \mathrm{~mol} \cdot \mathrm{kg}^{-1} \mathrm{OH}^{-}\right)$. The initial concentration of added $\mathrm{H}_{2}$ varied from zero (no hydrogen added) to $1.5 \cdot 10^{-4} \mathrm{~mol} \cdot \mathrm{kg}^{-1}$. In Figure 4 , the calculated steady-state concentration of $\mathrm{H}_{2} \mathrm{O}_{2}$ is presented as a function of the amount of added $\mathrm{H}_{2}$ for the dose rate (a) $1 \mathrm{kGy} \cdot \mathrm{s}^{-1}$ and (b) $10 \mathrm{kGy} \cdot \mathrm{s}^{-1}$.

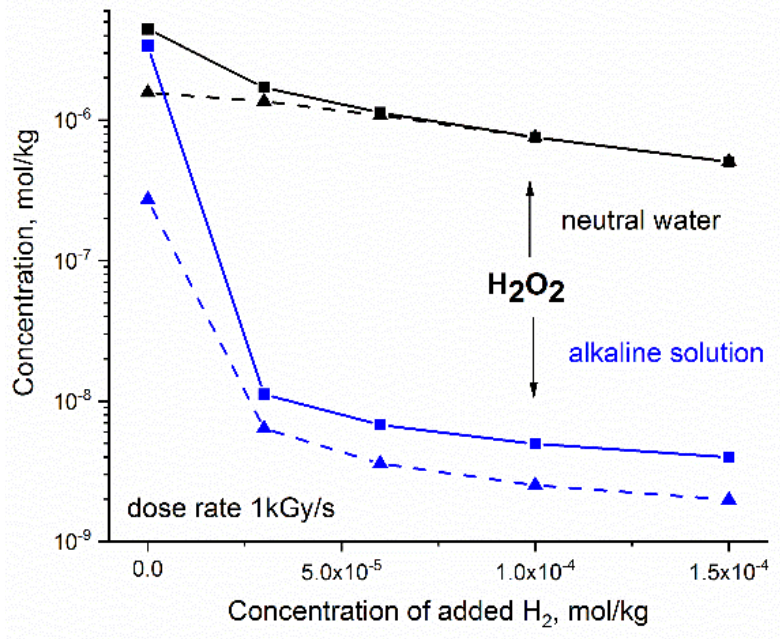

(a)

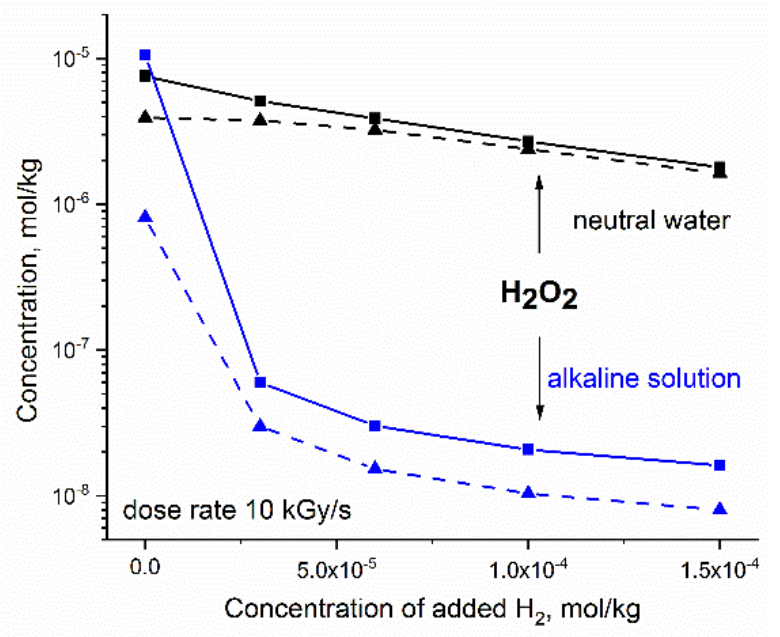

(b)

Figure 4. Simulated response of the steady state concentration of $\mathrm{H}_{2} \mathrm{O}_{2}$ to hydrogen addition to neutral water at $300{ }^{\circ} \mathrm{C}$ (black) and to alkaline solution containing $2 \cdot 10^{-4} \mathrm{~mol} \cdot \mathrm{kg}^{-1} \mathrm{OH}^{-}$ions (blue): (a) dose rate $1 \mathrm{kGy} \cdot \mathrm{s}^{-1} ;(\mathbf{b})$ dose rate $10 \mathrm{kGy} \cdot \mathrm{s}^{-1}$. Solid and dashed lines refer to fast neutron and gamma radiolysis, respectively.

Simulation shows that the addition of $\mathrm{H}_{2}$ to the alkaline solution results in a very significant decrease in $\left[\mathrm{H}_{2} \mathrm{O}_{2}\right]$. This synergic effect of $\mathrm{H}_{2}$ and $\mathrm{OH}^{-}$can be expected even at a small concentration of added hydrogen. The reduction in $\mathrm{H}_{2} \mathrm{O}_{2}$ is more effective for high-LET radiolysis and lower dose rate.

The steady concentration of $\mathrm{O}_{2}$ calculated vs. the increasing amount of $\mathrm{H}_{2}$ is presented in Figure 5. Compared with $\mathrm{H}_{2} \mathrm{O}_{2}$, the concentration of $\mathrm{O}_{2}$ responds significantly more to the amount of added $\mathrm{H}_{2}$. The reduction in $\mathrm{O}_{2}$ in neutral water is not very sensitive to LET and dose rate. In the case of alkaline solution, the synergic effect of $\mathrm{H}_{2}$ and $\mathrm{OH}^{-}$is more pronounced for gamma radiolysis.

In Table 3, the effectiveness of hydrogen injection is expressed by a ratio of the steadystate concentration of $\mathrm{H}_{2} \mathrm{O}_{2}$ and $\mathrm{O}_{2}$ in the absence of extra hydrogen and in the presence of $1.5 \cdot 10^{-4} \mathrm{~mol} \cdot \mathrm{kg}^{-1} \mathrm{H}_{2}$. Data are shown as a function of dose rate $\left(1\right.$ and $\left.10 \mathrm{kGy} \cdot \mathrm{s}^{-1}\right)$, LET (fast neutron and gamma radiation), and $\mathrm{pH}$ (neutral and alkaline water at $300{ }^{\circ} \mathrm{C}$ ). An increase in $\mathrm{pH}$ enhances the reducing effect of $\mathrm{H}_{2}$. In the presence of base the effectiveness of $\mathrm{H}_{2}$ injection increases about one hundred times for $\mathrm{H}_{2} \mathrm{O}_{2}$ and by four orders of magnitude for $\mathrm{O}_{2}$. 


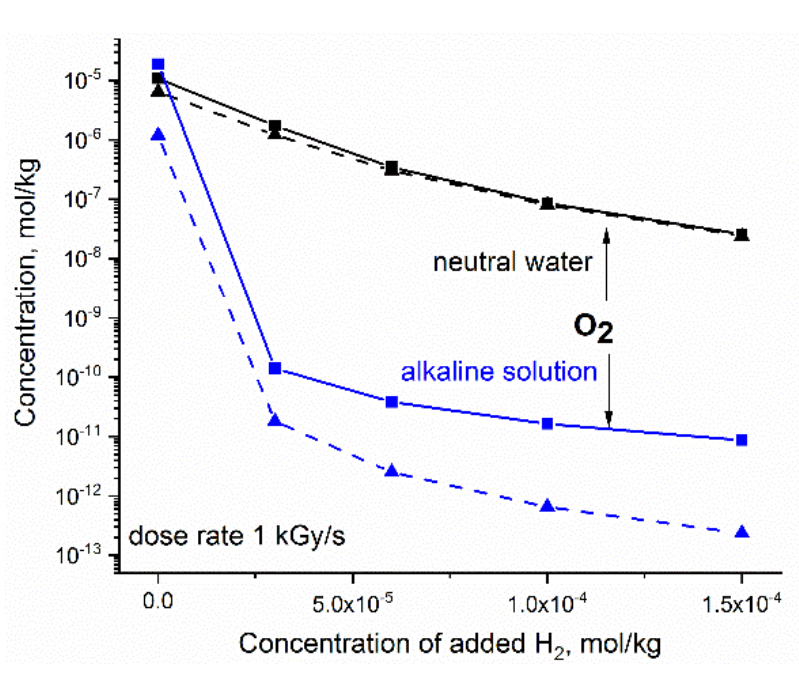

(a)

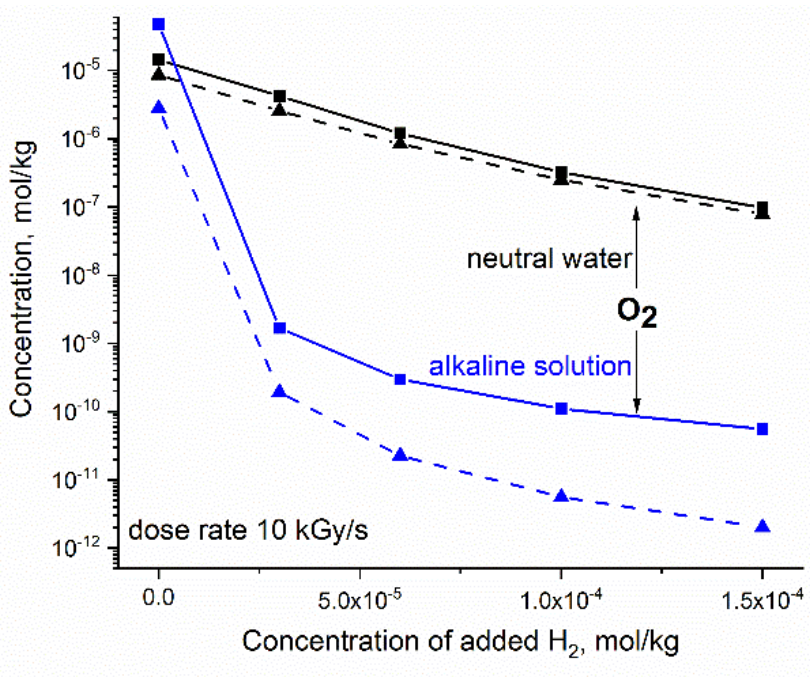

(b)

Figure 5. Simulated response of the steady state concentration of $\mathrm{O}_{2}$ to hydrogen added to neutral water at $300{ }^{\circ} \mathrm{C}$ (black) and to alkaline solution containing $2 \cdot 10^{-4} \mathrm{~mol} \mathrm{~kg}^{-1} \mathrm{OH}^{-}$ions (blue): (a) dose rate $1 \mathrm{kGy} \cdot \mathrm{s}^{-1} ;(\mathbf{b})$ dose rate $10 \mathrm{kGy} \cdot \mathrm{s}^{-1}$. Solid and dashed lines refer to fast neutron and gamma radiolysis, respectively.

Table 3. Effectiveness of hydrogen addition expressed as a ratio of the steady-state concentration in the absence of extra hydrogen and in the solution containing $1.5 \cdot 10^{-4} \mathrm{~mol} \cdot \mathrm{kg}^{-1} \mathrm{H}_{2}$.

\begin{tabular}{|c|c|c|}
\hline Oxidant/Solution & $\begin{array}{c}1 \mathrm{kGy} \cdot \mathrm{s}^{-1} \\
\text { Neutron } \gamma \text {-Radiolysis }\end{array}$ & $\begin{array}{c}10 \mathrm{kGy} \cdot \mathrm{s}^{-1} \\
\text { Neutron } \gamma \text {-Radiolysis }\end{array}$ \\
\hline $\mathrm{H}_{2} \mathrm{O}_{2} /$ neutral & $8.8 \cdot 10^{0} 3.1 \cdot 10^{0}$ & $4.2 \cdot 10^{0} 2.4 \cdot 10^{0}$ \\
\hline $\mathrm{H}_{2} \mathrm{O}_{2}$ /alkaline & $8.5 \cdot 10^{2} 1.4 \cdot 10^{2}$ & $6.5 \cdot 10^{2} 1.0 \cdot 10^{2}$ \\
\hline $\mathrm{O}_{2} /$ neutral & $4.2 \cdot 10^{2} 2.7 \cdot 10^{2}$ & $1.5 \cdot 10^{2} 1.1 \cdot 10^{2}$ \\
\hline $\mathrm{O}_{2} /$ alkaline & $2.2 \cdot 10^{6} 5.0 \cdot 10^{6}$ & $8.7 \cdot 10^{5} 1.4 \cdot 10^{6}$ \\
\hline
\end{tabular}

\section{Discussion}

The reaction schemes assumed for simulation by different groups vary at some points. To account for the different values of reported rate constants, the arithmetic mean was assumed as indicated in Table 2, and the following reactions were considered as parallel reactions: (1) and (57); (9) and (10); (14) and (15); (22), (23) and (55); (44) and (45); (52) and (53). The sensitivity of the results to the reaction scheme is discussed below.

\subsection{Significance of Reactions}

The significance of reactions was assessed based on the integrated (up to $100 \mathrm{~s}$ ) contributions $R$ of individual reactions, expressed in mol $\cdot \mathrm{kg}^{-1}$. Reactions contributing in less than $1 \cdot 10^{-4} \mathrm{~mol} \cdot \mathrm{kg}^{-1}$, which is the lowest integrated production rate at $1 \mathrm{kGy} \cdot \mathrm{s}^{-1}$ (Table 1), were considered insignificant. Simulation performed for the dose rate $1 \mathrm{kGy} \cdot \mathrm{s}^{-1}$ showed that skipping reactions (1), (22), (47), (52), (53), (55), and (56) results in a relative error of the steady-state concentrations of radiolytic products below $0.1 \%$, for all the systems studied.

The most significant are equilibrium reactions, but the assessment of their importance should take into account a net contribution of each equilibrium, expressed as a difference between the integrated contributions of forwarding and backward reactions. Figure 6 shows net contributions calculated for neutral water, alkaline solution, neutral and alkaline solutions containing $3 \cdot 10^{-5} \mathrm{~mol} \cdot \mathrm{kg}^{-1} \mathrm{H}_{2}$. The upper part presents net contributions R24-R25, R38-R39, R40-R41, R42-R43 of equilibria (24) $\leftrightarrow$ (25), (38) $\leftrightarrow$ (39), (40) $\leftrightarrow(41)$, $(42) \leftrightarrow(43)$, obtained for gamma and fast neutron irradiation, whereas the lower part refers 
to equilibria (26) $\leftrightarrow$ (27), (28) $\leftrightarrow$ (29), (34) $\leftrightarrow$ (35), (36) $\leftrightarrow$ (37). Net contributions R30-R31, R32-R33, R49-R50 are of the order of $10^{-7}-10^{-5} \mathrm{~mol} \cdot \mathrm{kg}^{-1}$ and are not shown in Figure 6.

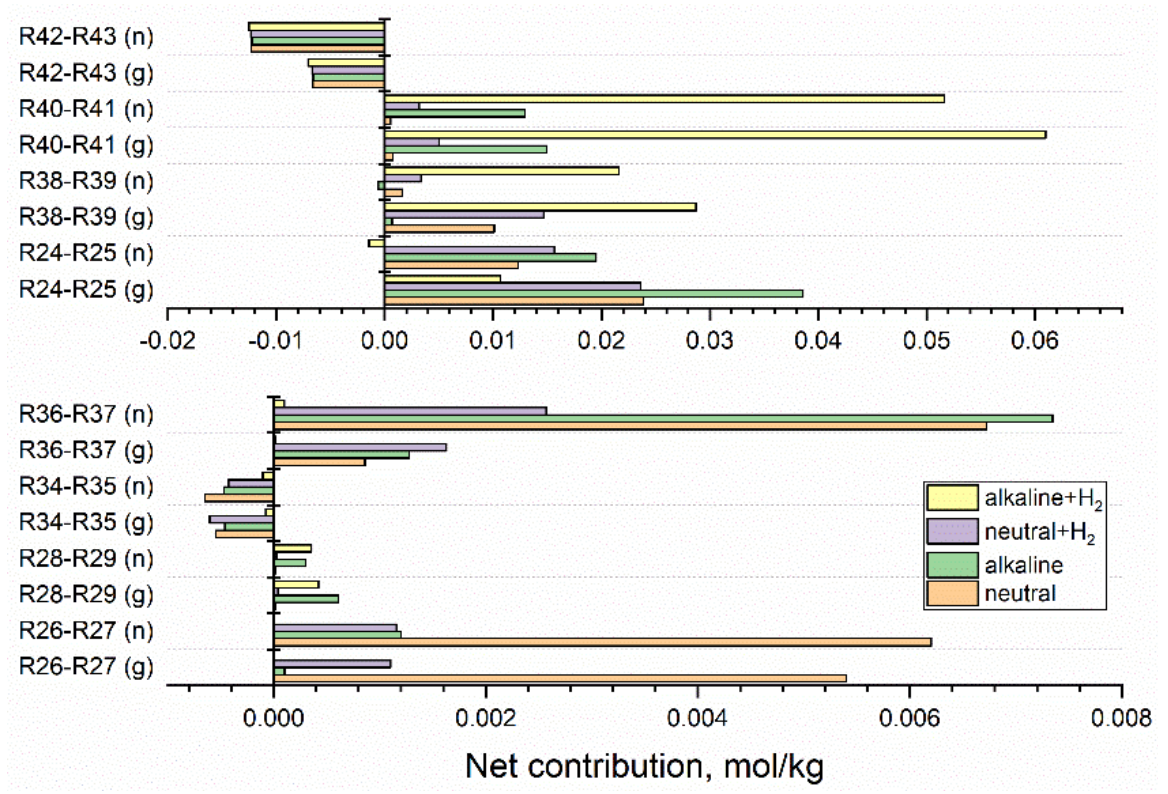

Figure 6. Net contributions of equilibria reactions calculated for $1 \mathrm{kGy} \cdot \mathrm{s}^{-1}$ fast neutron (n) and gamma $(\mathrm{g})$ radiolysis of neutral water, alkaline solution, and hydrogenated $\left(3 \cdot 10^{-5} \mathrm{~mol} \cdot \mathrm{kg}^{-1} \mathrm{H}_{2}\right)$ neutral and alkaline systems. Equilibria resulting in net contribution below $1 \cdot 10^{-4} \mathrm{~mol} \cdot \mathrm{kg}^{-1}$ are not shown.

Equilibria (24) $\leftrightarrow$ (25), (26) $\leftrightarrow$ (27), (28) $\leftrightarrow$ (29), (36) $\leftrightarrow$ (37), (38) $\leftrightarrow$ (39) (40) $\leftrightarrow(41)$, are shifted to the left, whereas equilibria (34) $\leftrightarrow$ (35), (42) $\leftrightarrow$ (43) are shifted to the right. The shift of equilibrium (42) $\leftrightarrow$ (43) towards reaction (43) is almost independent of the composition of solution and more meaningful in the systems irradiated by fast neutrons. Net contributions of equilibria (40) $\leftrightarrow(41)$ and (38) $\leftrightarrow$ (39) are highly enlarged in the alkaline solution containing $3 \cdot 10^{-5} \mathrm{~mol} \cdot \mathrm{kg}^{-1} \mathrm{H}_{2}$. The increased production of $\mathrm{e}_{\mathrm{aq}}{ }^{\bullet-}$ and $\mathrm{H}^{\bullet}$ enhances the reducing conditions.

The importance of other reactions is revealed in Scheme 3. The contributions, integrated up to $100 \mathrm{~s}$, were classified into the following three categories: (I) $1 \cdot 10^{-2} \leq R<$ $1 \cdot 10^{-1} \mathrm{~mol} \cdot \mathrm{kg}^{-1}$; (II) $1 \cdot 10^{-3} \leq R<1 \cdot 10^{-2} \mathrm{~mol} \cdot \mathrm{kg}^{-1}$; (III) $1 \cdot 10^{-4} \leq R<1 \cdot 10^{-3} \mathrm{~mol} \cdot \mathrm{kg}^{-1}$.

Compared with neutral water, the significance of reactions initiated by $\mathrm{e}_{\mathrm{aq}}{ }^{\bullet-}$, and the alkaline forms of ${ }^{\bullet} \mathrm{OH}$ and $\mathrm{HO}_{2}{ }^{\bullet}$, i.e., $\mathrm{O}^{\bullet-}$ and $\mathrm{HO}_{2}{ }^{-}$, is noticeably increased in the alkaline solution, whereas the increase in R6 and R12 seen for neutral hydrogenated system indicates more efficient scavenging of ${ }^{\bullet} \mathrm{OH}$ and $\mathrm{H}_{2} \mathrm{O}_{2}$ by $\mathrm{H}^{\bullet}$ in this system. The radiation chemistry of the alkaline hydrogenated solution is controlled by six reactions: (3), (4), (5), (7), (48), and (57). This is a consequence of significant left shifts of equilibria (40) $\leftrightarrow(41)$ and (38) $\leftrightarrow$ (39) (Figure 6). In irradiated alkaline hydrogenated solutions, the reducing conditions are maintained by simultaneous production of $\mathrm{e}_{\mathrm{aq}}{ }^{\bullet-}$ and $\mathrm{H}^{\bullet}$. 


\begin{tabular}{|l|l|l|l|l|l|l|l|l|l|l|l|l|}
\hline \multirow{2}{*}{ G } & \multicolumn{3}{|c|}{ Neutral } & \multicolumn{3}{c|}{ Alkaline } & \multicolumn{2}{|c|}{ Neutral + } & \multicolumn{3}{|c|}{ Alkaline + } \\
\hline & $\mathrm{H}_{2}$ & \multicolumn{2}{l|}{$\mathrm{H}_{2}$} \\
\hline & I & II & III & I & II & III & I & II & III & I & II & III \\
\hline R3 & & & & & & & & & & & & \\
\hline R4 & & & & & & & & & & & & \\
\hline R5 & & & & & & & & & & & & \\
\hline R6 & & & & & & & & & & & & \\
\hline R7 & & & & & & & & & & & & \\
\hline R8 & & & & & & & & & & & & \\
\hline R9 & & & & & & & & & & & & \\
\hline R10 & & & & & & & & & & & & \\
\hline R11 & & & & & & & & & & & & \\
\hline R12 & & & & & & & & & & & & \\
\hline R13 & & & & & & & & & & & & \\
\hline R14 & & & & & & & & & & & & \\
\hline R15 & & & & & & & & & & & & \\
\hline R16 & & & & & & & & & & & & \\
\hline R17 & & & & & & & & & & & & \\
\hline R18 & & & & & & & & & & & & \\
\hline R19 & & & & & & & & & & & & \\
\hline R44 & & & & & & & & & & & & \\
\hline R45 & & & & & & & & & & & & \\
\hline R46 & & & & & & & & & & & & \\
\hline R48 & & & & & & & & & & & & \\
\hline R51 & & & & & & & & & & & & \\
\hline R57 & & & & & & & & & & & & \\
\hline
\end{tabular}

(a) gamma-radiation

\begin{tabular}{|l|l|l|l|l|l|l|l|l|l|l|l|l|}
\hline \multirow{2}{*}{ FN } & \multicolumn{3}{|c|}{ Neutral } & \multicolumn{3}{|c|}{ Alkaline } & \multicolumn{2}{|c|}{ Neutral + } & \multicolumn{2}{|c|}{ Alkaline + } \\
\hline & $H_{2}$ & \multicolumn{2}{l}{$\mathrm{H}_{2}$} \\
\hline & I & II & III & I & II & III & I & II & III & I & II & III \\
\hline R3 & & & & & & & & & & & & \\
\hline R4 & & & & & & & & & & & & \\
\hline R5 & & & & & & & & & & & & \\
\hline R6 & & & & & & & & & & & & \\
\hline R7 & & & & & & & & & & & & \\
\hline R8 & & & & & & & & & & & & \\
\hline R9 & & & & & & & & & & & & \\
\hline R10 & & & & & & & & & & & & \\
\hline R11 & & & & & & & & & & & & \\
\hline R12 & & & & & & & & & & & & \\
\hline R13 & & & & & & & & & & & & \\
\hline R14 & & & & & & & & & & & \\
\hline R15 & & & & & & & & & & & & \\
\hline R16 & & & & & & & & & & & \\
\hline R17 & & & & & & & & & & & \\
\hline R18 & & & & & & & & & & & & \\
\hline R19 & & & & & & & & & & & \\
\hline R21 & & & & & & & & & & & \\
\hline R44 & & & & & & & & & & \\
\hline R45 & & & & & & & & & \\
\hline R46 & & & & & & & & & & \\
\hline R48 & & & & & & & & & & & \\
\hline R54 & & & & & & & & & & \\
\hline R57 & & & & & & & & & & & \\
\hline
\end{tabular}

(b) fast neutron-radiation

Scheme 3. Graphical presentation of importance of reactions from Table 2. The integrated contributions $R$ were classified into categories I, II, and III, defined in the text above the scheme. Colours correspond to neutral water (orange), alkaline solution (green), and hydrogenated $\left(3 \cdot 10^{-5} \mathrm{~mol} \cdot \mathrm{kg}^{-1} \mathrm{H}_{2}\right)$ systems: neutral (violet) and alkaline (yellow). Based on the simulation for $1 \mathrm{kGy} \cdot \mathrm{s}^{-1}$.

\subsection{Key Reactions Contributing to Production of Oxidants}

The simulations carried out in this study confirm that $\mathrm{H}_{2} \mathrm{O}_{2}$ and $\mathrm{O}_{2}$ are the main radiolytic products responsible for the formation of the oxidising environment in the coolant. The contributions of key reactions leading to the formation and decay of these oxidants in fast neutron (n) and gamma (g) radiolysis of neutral water and the alkaline solution are presented in Figures 7 and 8. The action of added hydrogen is shown for $\left[\mathrm{H}_{2}\right]=3 \cdot 10^{-5} \mathrm{~mol} \cdot \mathrm{kg}^{-1}$. Contributions of all reactions were integrated up to $100 \mathrm{~s}$.

Exposition of the coolant to ionising radiation results in the continuous production of $\mathrm{H}_{2} \mathrm{O}_{2}$ in zeroth-order reactions. In Figure 7, integrated production rates are represented by $\mathrm{P}(\mathrm{g})$ and $\mathrm{P}(\mathrm{n})$. Since the production rate of $\mathrm{H}_{2} \mathrm{O}_{2}$ by fast neutrons is higher (Table 1$), \mathrm{P}(\mathrm{n})$ exceeds $\mathrm{P}(\mathrm{g})$. At the small concentrations of base and $\mathrm{H}_{2}$, considered here, the production of $\mathrm{H}_{2} \mathrm{O}_{2}$ is independent of the composition of the irradiated system. Apart from the production, the formation of $\mathrm{H}_{2} \mathrm{O}_{2}$ is controlled by reactions (3), (14), (35), while reactions (7), (17), (34) determine the decay of $\mathrm{H}_{2} \mathrm{O}_{2}$. Since the contribution of reaction (35) prevails, the net contribution R35-R34 is shown in the upper panel. In the case of the neutral system, the most important source of $\mathrm{H}_{2} \mathrm{O}_{2}$ is production $\mathrm{P}(\mathrm{n})$ in neutron radiolysis, $\mathrm{P}(\mathrm{g})$ in gamma radiolysis, and reaction $\mathrm{R} 3(\mathrm{~g})$ in gamma-irradiated water.

The increase in $\mathrm{R} 3(\mathrm{~g})$ observed for the alkaline solution and hydrogenated neutral system is balanced by the decay of $\mathrm{H}_{2} \mathrm{O}_{2}$ in reaction with the radicals, $\mathrm{e}_{\mathrm{aq}}{ }^{\bullet-}$ and ${ }^{\bullet} \mathrm{OH}$. The synergic effect of $\mathrm{H}_{2}$ and $\mathrm{OH}^{-}$is seen in the diminishment of $\mathrm{R} 3(\mathrm{~g})$ obtained for the alkaline hydrogenated solution.

Contributions of key reactions directly responsible for the formation and decay of $\mathrm{O}_{2}$ are displayed in Figure 8.

In neutral and hydrogenated neutral systems, $\mathrm{O}_{2}$ decays in reactions (13) and (8) producing $\mathrm{HO}_{2}{ }^{\bullet}$ and $\mathrm{O}_{2}{ }^{\bullet-}$, which reform $\mathrm{O}_{2}$ in reactions (19) and (18) with ${ }^{\bullet} \mathrm{OH}$. The 
contribution of reactions (8) and (18) is significantly increased in the alkaline solution, but the restoration of $\mathrm{O}_{2}$ is less productive. Thus, the net effect is a reduction in the concentration of $\mathrm{O}_{2}$. In the hydrogenated alkaline system, the contribution of reactions (18) and (19) is of the order of $10^{-5}$ and $10^{-6} \mathrm{~mol} \cdot \mathrm{kg}^{-1}$, respectively, and the formation of $\mathrm{O}_{2}$ is suppressed (Figure 5).

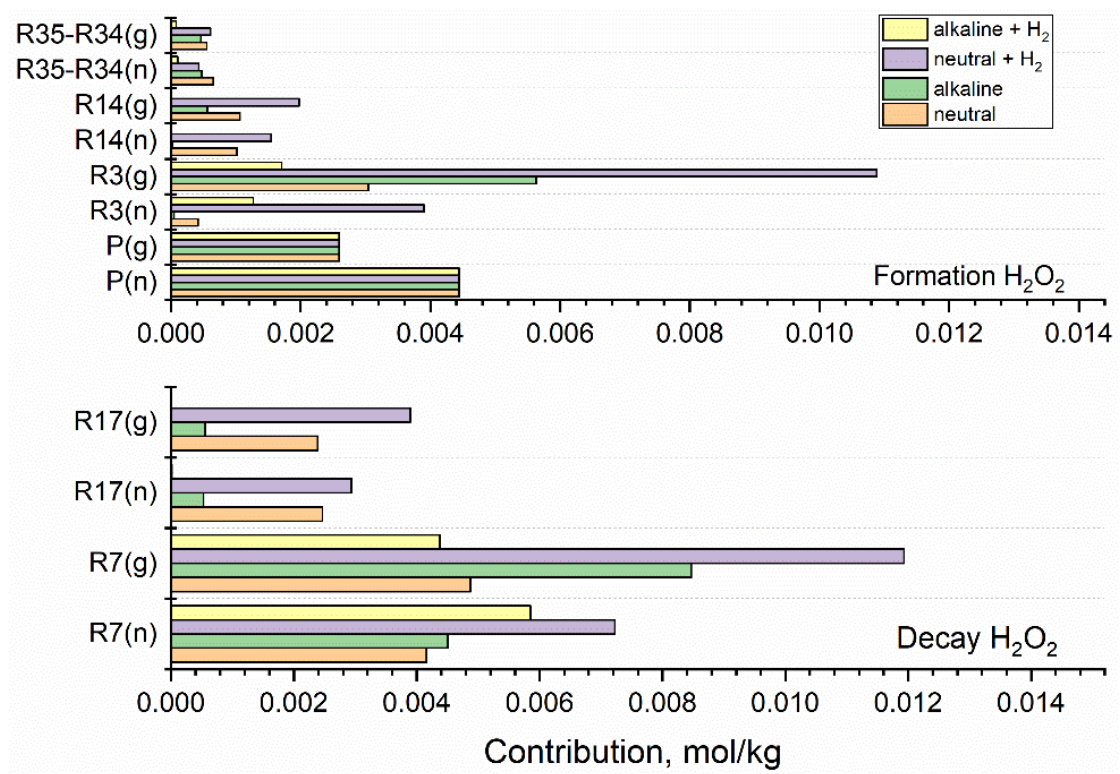

Figure 7. Integrated contributions of key reactions responsible for the formation and decay of $\mathrm{H}_{2} \mathrm{O}_{2}$ calculated for fast neutron (n) and gamma (g) radiolysis of neutral water, alkaline solution, and hydrogenated $\left(3 \cdot 10^{-5} \mathrm{~mol} \cdot \mathrm{kg}^{-1} \mathrm{H}_{2}\right)$ neutral and alkaline systems. Integrated production rates are represented by $\mathrm{P}(\mathrm{g})$ and $\mathrm{P}(\mathrm{n})$. Based on the simulation for $1 \mathrm{kGy} \cdot \mathrm{s}^{-1}$.
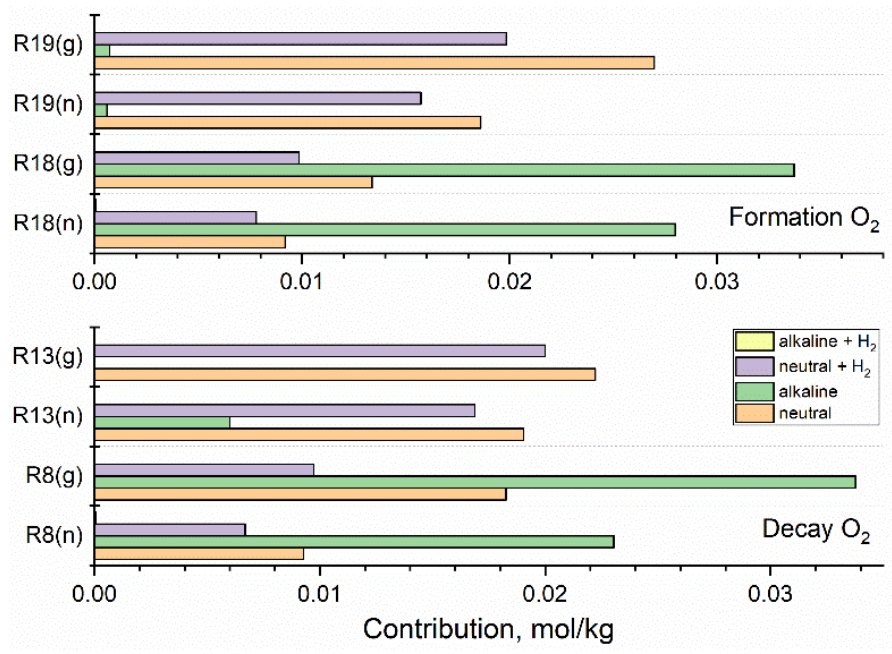

Figure 8. Contribution of key reactions responsible for the formation and decay of $\mathrm{O}_{2}$ calculated for fast neutron (n) and gamma (g) radiolysis of neutral water, alkaline solution, and hydrogenated $\left(3 \cdot 10^{-5} \mathrm{~mol} \cdot \mathrm{kg}^{-1} \mathrm{H}_{2}\right)$ neutral and alkaline systems. Based on the simulation for $1 \mathrm{kGy} \cdot \mathrm{s}^{-1}$.

\section{Conclusions}

Simulation of water chemistry at $300{ }^{\circ} \mathrm{C}$ and under exposure to ionising radiation was performed using the hybrid method [14] and the measured rate constant of $\mathrm{H}^{\bullet}+\mathrm{H}_{2} \mathrm{O} \rightarrow$ $\bullet \mathrm{OH}+\mathrm{H}_{2}$ reaction [22]. The steady-state concentration of oxidants $\left(\mathrm{O}_{2}, \mathrm{H}_{2} \mathrm{O}_{2}, \mathrm{HO}_{2}{ }^{\bullet}, \bullet \mathrm{OH}\right)$ were calculated for neutral water $\left(\mathrm{pH}_{573 \mathrm{~K}}=5.8\right)$ and an alkaline solution $\left(\mathrm{pH}_{573 \mathrm{~K}}=8.0\right)$, as a function of added hydrogen $\left(0 \leq\left[\mathrm{H}_{2}\right] \leq 1.5 \cdot 10^{-4} \mathrm{~mol} \cdot \mathrm{kg}^{-1}\right)$, dose rate $\left(1\right.$ and $\left.10 \mathrm{kGy} \cdot \mathrm{s}^{-1}\right)$, and the fraction of $\gamma$ rays $\left(0 \leq f_{\mathrm{g}} \leq 1\right)$ in the mixed fast neutron-gamma radiation. The 
concentration of main oxidants $\left(\mathrm{O}_{2}, \mathrm{H}_{2} \mathrm{O}_{2}\right)$ increases with the dose rate but decreases with the increasing fraction of $\gamma$ rays. At higher $\mathrm{pH}$ and $f_{\mathrm{g}}>0.3$ the total amount of $\mathrm{O}_{2}, \mathrm{H}_{2} \mathrm{O}_{2}$ is noticeably diminished. The simulation indicates that the addition of $\mathrm{H}_{2}$ to the alkaline solution effectively suppresses the formation of oxidising environment. This synergic effect of $\mathrm{H}_{2}$ and $\mathrm{OH}^{-}$may lower $\mathrm{CHC}$.

The importance of reactions contributing to the coolant radiolysis (Table 2) by fast neutrons and $\gamma$ rays was discussed for neutral, deaerated water and the alkaline solution, and both of these systems contained $3 \cdot 10^{-5} \mathrm{~mol} \cdot \mathrm{kg}^{-1} \mathrm{H}_{2}$.

The synergic effect of hydrogen gas and base added to the coolant, demonstrated in this study, provides an important guideline for the development of more efficient methods for controlling the oxidising environment and minimising corrosion problems in PWR engineering.

Funding: This research received no external funding.

Institutional Review Board Statement: Not applicable.

Informed Consent Statement: Not applicable.

Acknowledgments: The author thanks Lukasz Kazmierczak for collecting the literature data on reaction rate constants.

Conflicts of Interest: The author declares no conflict of interest.

\section{References}

1. Kawamura, H.; Shoda, Y.; Terachi, T.; Katsumura, Y.; Uchida, S.; Mizuno, T.; Muroya, Y.; Tsuzuki, Y.; Umehara, R.; Hirano, H.; et al. PWR secondary water chemistry guidelines in Japan-Purpose and technical background. Prog. Nucl. Energy 2019, 114, 121-137. [CrossRef]

2. Takagi, J.; Mincher, B.J.; Yamaguchi, M.; Katsumura, Y. Radiation chemistry in nuclear engineering. In Charged Particle and Photon Interactions with Matter. Recent Advances, Applications, and Interfaces; Hatano, Y., Katsumura, Y., Mozumder, A., Eds.; CRC Press Taylor \& Francis Group: Boca Raton, FL, USA; London, UK; New York, NY, USA, 2011; pp. 960-1023.

3. Buxton, G.V. The radiation chemistry of liquid water. In Charged Particle and Photon Interactions with Matter; Hatano, Y., Mozumder, A., Eds.; Marcel Dekker: New York, NY, USA, 2003; pp. 331-364.

4. Wada, Y.; Watanabe, A.; Tachibana, M.; Ishida, K.; Uetake, N.; Uchida, S.; Akamine, K.; Sambongi, M.; Suzuki, S.; Ishigure, K. Effects of hydrogen peroxide on intergranular stress corrosion cracking of stainless steel in high temperature water, (IV). J. Nucl. Sci. Technol. 2012, 38, 183-192. [CrossRef]

5. Raiman, S.S.; Was, G.S. Accelerated corrosion and oxide dissolution in 316L stainless steel irradiated in situ in high temperature water. J. Nucl. Mater. 2017, 493, 207-218. [CrossRef]

6. Doyle, P.; Sun, K.; Snead, L.; Katoh, Y.; Bartels, D.; Zinkle, S.; Raiman, S. The effects of neutron and ionizing irradiation on the aqueous corrosion of SiC. J. Nucl. Mater. 2020, 536, 152190. [CrossRef]

7. Ibe, E.; Uchida, S. A water radiolysis model in a circulating flow system with a boiling region and its application to hydrogen alternate, water chemistry of boiling water reactors. Nucl. Sci. Eng. 1985, 90, 140-157. [CrossRef]

8. Sunaryo, G.R.; Katsumura, Y.; Ishigure, K. Radiolysis of water at elevated temperatures-III. Simulation of radiolytic products at 25 and $250{ }^{\circ} \mathrm{C}$ under irradiation with $\gamma$-rays and fast neutrons. Radiat. Phys. Chem. 1995, 45, 703-714. [CrossRef]

9. Christensen, $\mathrm{H}$. Remodeling of the oxidant species during radiolysis of high-temperature water in a pressurized water reactor. Nucl. Technol. 1995, 109, 373-382. [CrossRef]

10. Swiatla-Wojcik, D.; Buxton, G.V. Modelling Radiolysis of Water Coolant under Operating Conditions. In Proceedings of the 23rd Miller Conference in Radiation Chemistry, Białowieża, Poland, 6-12 September 2003.

11. Takiguchi, H.; Ullberg, M.; Uchida, S. Optimization of dissolved hydrogen concentration for control of primary coolant radiolysis in pressurized water reactors. J. Nucl. Sci. Technol. 2004, 41, 601-609. [CrossRef]

12. Bartels, D.M.; Henshaw, J.; Sims, H.E. Modeling the critical hydrogen concentration in the AECL test reactor. Radiat. Phys. Chem. 2013, 82, 16-24. [CrossRef]

13. Lertnaisat, P.; Katsumura, Y.; Mukai, S.; Umehara, R.; Shimizu, Y.; Suzuki, M. Primary yields and reaction sets with corresponding rate constants for computer simulation of water radiolysis at elevated temperature. J. Nucl. Sci. Technol. 2016, 53, 1816-1823. [CrossRef]

14. Swiatla-Wojcik, D. Hybrid method for numerical modelling of LWR coolant chemistry. Radiat. Phys. Chem. 2016, 127, 236-242. [CrossRef]

15. Christensen, H. Fundamental aspects of water coolant radiolysis. In SKI Report 2006:16; Swedish Nuclear Power Inspectorate: Nyköping, Sweden, 2006. 
16. Elliot, A.J.; Bartels, D.M. The reaction set, rate constants and g-values for the simulation of the radiolysis of light water over the range 20 to $350{ }^{\circ} \mathrm{C}$ based on information available in 2008. In Report AECL-153-127160-450-001; Chalk River Laboratories: Chalk River, ON, Canada, 2009.

17. Swiatla-Wojcik, D.; Buxton, G.V. On the possible role of the reaction $\bullet \mathrm{H}^{-} \mathrm{H}_{2} \mathrm{O} \rightarrow \mathrm{H}_{2}+{ }^{\bullet} \mathrm{OH}$ in the radiolysis of water at high temperatures. Radiat. Phys. Chem. 2005, 74, 210-219. [CrossRef]

18. Bartels, D.M. Comment on the possible role of the reaction ${ }^{\bullet} \mathrm{H}+\mathrm{H}_{2} \mathrm{O} \rightarrow \mathrm{H}_{2}+\bullet \mathrm{OH}$ in the radiolysis of water at high temperatures. Radiat. Phys. Chem. 2009, 78, 191-194. [CrossRef]

19. Swiatla-Wojcik, D.; Buxton, G.V. Reply to comment on the possible role of the reaction $\bullet \mathrm{H}+\mathrm{H}_{2} \mathrm{O} \rightarrow \mathrm{H}_{2}+{ }^{\bullet} \mathrm{OH}$ in the radiolysis of water at high temperatures. Radiat. Phys. Chem. 2010, 79, 52-56. [CrossRef]

20. Sanguanmith, S.; Muroya, Y.; Meesungnoen, J.; Lin, M.; Katsumura, Y.; Mirsaleh Kohan, L.; Guzonas, D.A.; Stuart, C.R.; Jay-Gerin J.-P. Low-linear energy transfer radiolysis of liquid water at elevated temperatures up to $350^{\circ} \mathrm{C}$ : Monte-Carlo simulations. Chem. Phys. Lett. 2011, 508, 224-230. [CrossRef]

21. Alcorn, C.D.; Brodovitch, J.-C.; Percival, P.W.; Smith, M.; Ghandi, K. Kinetics of the reaction between H and superheated water probed with muonium. Chem. Phys. 2014, 435, 29-39. [CrossRef]

22. Muroya, Y.; Yamashita, S.; Lertnaisat, P.; Sanguanmith, S.; Meesungnoen, J.; Jay-Gerin, J.-P.; Katsumura, Y. Rate constant for the $\mathrm{H}^{\bullet}+\mathrm{H}_{2} \mathrm{O} \rightarrow{ }^{\bullet} \mathrm{OH}+\mathrm{H}_{2}$ reaction at elevated temperatures measured by pulse radiolysis. Phys. Chem. Chem. Phys. 2017, 19, 30834-30841. [CrossRef] [PubMed]

23. Kazmierczak, L.; Szala-Bilnik, J.; Wolszczak, M.; Swiatla-Wojcik, D. Temperature dependence of the rate constant for hydrogen atom reaction with $\mathrm{Cl}_{2}{ }^{-\bullet}$ in water by pulse radiolysis of aqueous $\mathrm{HCl}$ solution. Radiat. Phys. Chem. 2015, 117, 7-11. [CrossRef]

24. Swiatla-Wojcik, D. Modelling spur chemistry for alkaline and acidic water at high temperatures. Res. Chem. Intermed. 2009, 35, 519-530. [CrossRef]

25. Ichikawa, N.; Takagi, J. Precise evaluation of corrosion environments of structural materials under complex water flow conditions (II). J. Nucl. Sci. Technol. 2003, 40, 941-950. [CrossRef]

26. Swiatla-Wojcik, D. Water-structure based mechanistic view on the bimolecular decay of the hydrated electron. Chem. Phys. Lett. 2015, 641, 51-56. [CrossRef] 